\title{
Bridges, tunnels, and ferries: connectivity, transport, and the future of Hong Kong's outlying islands
}

\author{
Abraham Leung \\ Griffith University, Australia \\ abraham.leung@griffith.edu.au \\ Michael Tanko \\ KTH Royal Institute of Technology, Sweden \\ tanko@kth.se \\ Matthew Burke \\ Griffith University, Australia \\ m.burke@griffith.edu.au
}

and

\section{C.S. Shui \\ University of Hong Kong, Hong Kong \\ csshui@hku.hk}

\begin{abstract}
Hong Kong has numerous outlying islands that are relatively underdeveloped due to isolation from the urban core and are dependent on ferries. Concurrently, the Hong Kong Government has expressed a desire for outlying islands to be places for urban expansion and has proposed building more bridges, tunnels, and reclaimed land. Development of these fixed links may transform the outlying island communities' current ways of life. Ferry operators struggle to maintain efficient operation, fleet investments, improved services, and attract passengers while competing with fixed link transport modes. Urban ferry transport has been resurgent in parts of Europe, North America, and Australia, but not Hong Kong. This paper identifies a new typology of island communities according to connectivity based on available transport links. Using census and ferry statistics, the socioeconomic development of island communities is analysed. The transport problems faced by outlying islands are further conceptualised, and possible scenarios for socially sustainable island futures are proposed.
\end{abstract}

Keywords: connectivity, ferry services, fixed links, islands, Hong Kong, transport

https://doi.org/10.24043/isj.24

(C) 2017 - Institute of Island Studies, University of Prince Edward Island, Canada.

\section{Introduction}

Before the development of railways and automobiles, ferry transport was the most efficient form of passenger and freight transport in coastal and river cities. Most cities were built near riverbanks or harbours, with easy access to waterways. However, in recent times ferries have increasingly been replaced by fixed transport links, such as bridges, tunnels, and causeways, especially as construction and engineering technology has advanced. This pattern has been visible in Hong Kong, a city comprised of a peninsula and 263 islands. The city's rapid evolution from a water-based transport network into a rail and road-based metropolis offers insights into how island cities evolve over time. 
This paper examines the changes that Hong Kong's island communities have undergone over the past 20 years. The paper: i) explores the trajectory of ferry operations in Hong Kong; ii) suggests a typology of island communities in Hong Kong based on their transport connections; iii) identifies possible impacts of future expansion of fixed links and a continued land reclamation program; and iv) suggests whether the current development model is sustainable. Section 1 briefly outlines the literature on island studies and water-based transport. Section 2 presents the case of Hong Kong's island communities, covering the emergence of land-based modes, the comparison of fixed links and ferries, and the situation in Hong Kong. Section 3 reviews archival material and census statistics which describe the evolution of outlying island communities. Section 4 shifts to considering alternative international experiences with ferry-oriented development (FOD). Section 5 provides a detailed analysis of island communities in Hong Kong. Section 6 identifies key factors in successful ferry-connected cities and suggests possible implications of measures that improve ferry access in waterfronts areas. Section 7 concludes the paper.

\section{Transport of urban islands: the fixed link or ferries debate}

Island studies is a growing research area that conceptualises islands as unique cases of urban formation and related processes of development. Islands, in a literal sense, are land masses enclosed by water (Eichhorn, 2016). Over the course of human civilisation, via advances in shipbuilding and marine navigation technology, these individual land masses initially became connected by water-borne transport modes. Ferries had the advantages of low infrastructure investment as only vessels, piers, and navigation guides were needed. However, in modern times transport on water has become less efficient compared to land-based modes. Most water-divided cities began to connect islands either through fixed link infrastructure (bridges, causeways, and later tunnels) or by creating new land to create connections (land reclamation).

These processes have fundamentally challenged the notion of 'islandness'; that is of being isolated or separated (Hay, 2006). With increases in land-based connections, many islands have increasingly become integral to the associated 'mainland' and are no longer perceived as islands (Pigou-Dennis \& Grydehøj, 2014). Due to relative isolation, urban settlements located on islands often form distinct cultures or customs. Contemporary evidence in South Korea has shown that islands connected by fixed links become part of the mainland lose distinct island cultures (Kim, 2016). Some residents on Canada's west coast islands have opposed fixed links and counterintuitively prefer 'inconvenience' as a virtue that preserves islands' environment and social fabric (Vannini, 2011). Whether bridge or land connected islands should still be considered islands therefore remains a geographic question in defining islands and how they have developed (Källgard, 2005). Recently in Scotland, a government Bill was introduced to help protect and sustain island communities. This Bill defined an 'island community' as a community that 'consists of two or more individuals, all of whom permanently inhabit an island (whether or not the same island), and is based on common interest, identity or geography' (Scottish Parliament, 2017, p. 1). We adopt this definition in the rest of our paper.

The population size of island communities is often limited by transport constraints occasioned by limited transport options and difficulties in maintaining levels of service (Murray \& Davis, 2001). During recent oil price increases, ferries have also been deemed more vulnerable, as ferries rely mostly on petroleum fuels such as diesel (Leung et al., 2016). Waterborne transport faces reliability issues and is subject to breakdowns and adverse weather conditions (Knowles, 1996). Because of the threat of isolation, the welfare of island residents may also be affected by the limited supply of perishable goods such as food, resulting in higher living costs (Calderwood \& Freathy, 2011). Increased transport costs may affect island economies as they are often dependent on tourism (Yeoman et al., 2007). Such costs and reliability concerns are often used to justify building fixed links, or using land reclamation to create road or rail connections. However, these links often require a certain population threshold or development level to justify capital costs (Grydehøj, 2015a). Well-documented cases 
include Sinophone cities such as Xiamen, Guangzhou, Macau, Kaohsiung, Singapore, and Hong Kong (Barter, 2007). There are other examples in Europe (e.g. Copenhagen, Venice, Rotterdam; see Knowles, 2000), North America (e.g. New York, Miami, Prince Edward Island; see Baldacchino, 2007), the Middle East (Dubai, Abu Dhabi, Bahrain); and India (e.g. Mumbai, Kochi; Swaminathan, 2015).

Fixed links and reclamation can be highly contested, however, because of potential environmental and social impacts, with large-scale engineering works often opposed by environmental groups (e.g. the Confederation Bridge case on Prince Edward Island, Canada as showcased by Baldacchino (2007)). While the energy savings of land-based transport are sometimes used to justify fixed link construction, especially if mass transport modes are provided, these may not necessarily outcompete ferry operations. The energy costs of ferry operation actually vary greatly, subject to ship size, operation speed, distance, and occupancy (Baird \& Pedersen, 2013; Becken, 2002; Cottrell, 2011) and also differing geographical conditions (Newman \& Kenworthy, 2011).

Yet ferries systems have continued to evolve with the provision of fixed links, as seen in London, New York, Brisbane, and Sydney. Such systems have adapted to co-exist with fixed link transport and have been incorporated into programs revitalising waterfront areas (Fox, 2016; Tanko \& Burke, 2016; Weisbrod \& Lawson, 2003). A new form of waterfront development around ferry terminals has emerged, labelled Ferry-Oriented Development (FOD) (Sipe \& Burke, 2011), an adaptation of the more established Transit-Oriented Development (TOD) (Cervero, 2004). From a transport and land use policy perspective, ferries are increasingly seen as an option for harnessing the underused transport capacity of waterways with the potential to reduce road-based traffic congestion and air pollution (Stenius et al., 2014). Recent advances in boat technology, such as higher speed low-wash vessels, can also close the gap in time savings that bridges have previously held. Ferries enjoy another important advantage over other transit modes: there is an attraction to the water that is deeply rooted in the human psyche and there is evidence that waterborne transport is preferred over other modes (Kamen \& Barry, 2011; Soumoy \& Sweeny, 2000; Tanko \& Burke, 2016). Indeed, it is partly on this basis that land developers seek ferry provision, subsidised by the public sector, to facilitate FOD and to attract developments and residents. The environmental impact of ferries can also be further reduced by cleaner fuel technology or even alternative fuels such as electric or solar powered vessels, which are under trial (Moirangthem \& Baxter, 2016).

In the case of Hong Kong, however, a renaissance in ferry operations has not occurred. Ferries have received comparatively little government support, with many routes cancelled due to low passenger numbers in recent decades. FOD of the kind being employed in Brisbane, New York, and Gothenburg to revitalise defunct port precincts away from mass transit (Tanko \& Burke, 2016) is mostly absent in Hong Kong. Instead, fixed links have been continuously expanded and further proposals from the government have been made to connect several outlying islands to create land for future urban development (Hong Kong Development Bureau, 2016a). To understand why ferries and FOD have not been embraced in Hong Kong and the government's preference for fixed links, some understanding of the history and development of Hong Kong's island communities is needed. The following section describes the background of Hong Kong's urban island evolution, and a typology of Hong Kong's island communities based on connectivity (fixed links or water-based modes) is proposed.

\section{Urban transport in Hong Kong: from ferry-oriented development to fixed links}

Hong Kong and Macau are unique island cities on the Chinese coast with significant western influence. Before its British acquisition, Hong Kong was initially considered as a 'barren rock' with little significance, having been a simple fishing village on the far periphery of the Chinese Qing Empire (Le Pichon, 2006, pp. 39-40). Ceded to the British from 1841 to 1997, Hong Kong developed rapidly due to its strategic location, natural deep-water harbour, and relative isolation from the political and military upheavals in China. The city is today a global financial and transportation hub. Like many other island cities obtained by colonial powers, constrained land availability necessitated a way to increase land supply to meet the needs of the population and economic growth (Grydehøj, 2015b). 
Hong Kong's territory is comprised of Hong Kong Island, peninsular Kowloon and the New Territories, and over two hundred islands of different sizes and populations. Because of its geography, boats were initially the main mode of transport connecting the various locations in Hong Kong, producing a traditional form of FOD. There was a lack of comprehensive urban planning, and provision of bridges was low due to the neglect of the British authorities, seeing Hong Kong as a far-flung outpost and a "borrowed place with borrowed time" (Hughes, 1976, p. 1).

It was only until after World War II when Hong Kong recovered from Japanese occupation that the first comprehensive town planning report, known as Hong Kong Preliminary Planning Report (Abercrombie, 1948), was completed. This plan helped shape Hong Kong's urban form by proposing a harbour connection (which was later realised as a tunnel) and new towns in the New Territories to accommodate rapid population growth (Lai, 1999). The proposals outlined in Abercrombie's Report were finalised in the Colony Outline Plan (Hong Kong Crown Lands and Survey Office, 1966, p. 1), accompanied by the establishment of the Transport Department in 1968. The Transport Department subsequently conducted a mass transport study plan as a first step in tackling increasing congestion problems. Following the opening of the first Cross Harbour Tunnel in 1972, ferry passenger numbers dropped significantly (Pang, 2001). The First Comprehensive Transport Study (CTS-l) was created (Wilbur Smith and Associates, 1976), which resulted in the decision to construct the Mass Transit Railway (MTR), and which also sought to restrict private vehicle travel. MTR expansion continued as rail was seen as the backbone for expanding urban growth to the New Territories satellite cities. These new towns accommodated population growth outside the urban core of Kowloon and Hong Kong Island (Loo \& Chow, 2011; Tiry, 2003). As in the case of Denmark (Knowles, 2000), Hong Kong slowly but surely replaced much of its water-based transport with fixed links. The once-bustling waterfronts reduced in importance compared to the transit-oriented development that was opened up by the MTR system.

Other shifts transformed islands outside of the urban core. In the run-up to the handover of Hong Kong to China in 1997, there was a large-scale programme to relocate the original Kai Tak Airport from Kowloon to the artificial island of Chek Lap Kok, north of Lantau. This project incorporated the Tsing Ma Bridge, which connected Lantau, the largest island in Hong Kong, to central Hong Kong. These developments relegated the once-thriving ferry services to an ancillary mode. The slow and outdated ferry routes failed to be modernised or integrated meaningfully into the mass transit system. Territory-wide ferry passenger numbers dropped from $8 \%$ in the 1970 s to just around $1 \%$ today (see Table 1). The most recent significant decline was in 2003, when the Tuen Mun to Central ferry services ceased to operate when West Rail was built to serve the northwest New Territories.

Table 1: Mode share of public transport modes in Hong Kong, 1978-2016 (\%).

\begin{tabular}{|l|l|l|l|l|}
\hline Year & Rail & Bus & Ferry & Taxi \\
\hline $\mathbf{1 9 7 8}$ & 6.92 & 73.57 & 8.53 & 10.98 \\
\hline $\mathbf{1 9 8 8}$ & 27.33 & 58.45 & 3.60 & 10.62 \\
\hline $\mathbf{1 9 9 8}$ & 34.11 & 54.65 & 1.68 & 9.57 \\
\hline $\mathbf{2 0 0 8}$ & 36.81 & 52.53 & 1.29 & 9.38 \\
\hline $\mathbf{2 0 1 6}$ & 42.60 & 48.95 & 1.04 & 7.41 \\
\hline
\end{tabular}

(Source: Compiled from Hong Kong Transport Department's Monthly Traffic and Transport Digest and Census and Statistics Department Public Transport Patronage of Hong Kong Series)

However, outlying island communities with significant populations continued to rely on water-based transport modes. For these areas, ferries still provided essential passenger movement, as well as supported tourism. The scheduled ferry routes operational in 2015 in Hong Kong are indicated by the blue lines in Figure 1. 


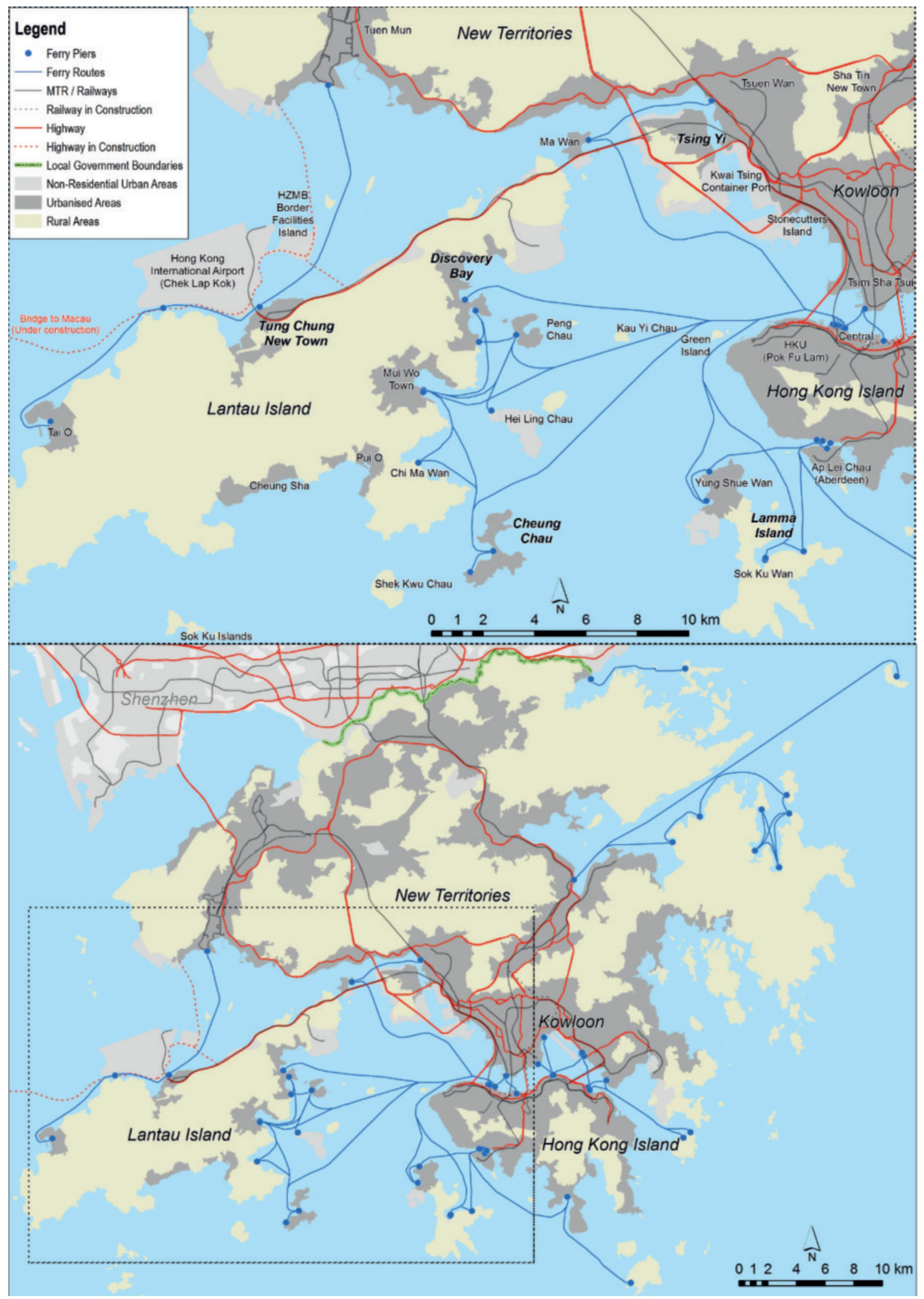

Figure 1: Scheduled ferry public transport (blue line) and fixed links (red and yellow lines) of Hong Kong, connecting various islands as of 2015. (Source: (C) Abraham Leung) 
In 1991, a cross-harbour transport study recommended the cancellation of many crossharbour services to make way for reclamation (Hong Kong Transport Department, 1991). But no replacement services were proposed as it was anticipated that fixed links (e.g. the Western Harbour Crossing) would be used to meet travel demand, with little mention of the role of ferries either during or after construction. Continued expansion of fixed links and reclamation is seen as part of Hong Kong's future development. However, with concerns regarding the narrowing of the harbour, along with growing environmental concerns and citizen activism, the modus operandi of 'fill, build and develop' has been increasingly questioned ( $\mathrm{Ng} \&$ Cook, 1997). Increased environmental activism to protect Victoria Harbour, as well as concern for an endangered species of Chinese White Dolphin, have led to the enactment of the Harbour Protection Bill, which makes further reclamation in Victoria Harbour difficult as a legal test of 'overriding public need' is required $(\mathrm{Ng}, 2006)$. As a result of ongoing citizen engagement, the environmentally sensitive Green Island was spared from being physically linked with Hong Kong Island. Subsequent new reclamation proposals on Hong Kong Island's waterfront also met with fierce opposition $(\mathrm{Ku}, 2012)$. This success has led to a freeze on reclamation projects since the early 2000s. But alternative visions of FOD have been less prominent. Instead, talks of using reclamation to address land shortage and housing affordability concerns have recently been re-floated with ambitious plans to reclaim the areas and waters around Lantau Island.

Earlier proposals for a 'mega-bridge' connecting Hong Kong on the eastern bank of the Pearl River Delta to Zhuhai on the western side were mooted way back in the 1980s (Toland, 2017). It was not until 2009 that decisions were made to construct the Hong Kong-Zhuhai-Macau Bridge (HZMB) which would leverage development opportunities across the entire northern and eastern Lantau (Hong Kong Government, 2013; Lantau Development Advisory Committee, 2016). More reclamation and fixed links are proposed, which are discussed in greater detail in the next section. Environmental groups, however, have questioned the need for further development and the mantra of growth, suggesting instead the importance of preserving the natural environment and maintaining the unique leisure value of Lantau as a green space (Hong Kong Legislative Council, 2016). This presents a dilemma for island communities that will be affected, with resident and business desires for better linkages to increase economic development and reduce social exclusion either via new fixed links or to embrace a context-specific vision of contemporary FOD, based around fast ferries (like those used in Gothenburg, Brisbane, and New York) to attract capital to less accessible places away from mass transit. However, there is little evidence that options for contemporary forms of FOD are being realised in Hong Kong. Before we explore this issue though, it is important to understand Hong Kong's different types of island communities.

\section{Conceptual framework for a typology of island communities based on transport connectivity}

Island communities are often seen as similar, being isolated and far to reach, but they are in fact quite diverse (Vannini \& Taggart, 2013). It is useful then to develop a conceptual framework to categorise various types of island communities and their characteristics. This is often done by identifying common features with the advantage of allowing generalisation and applicability across geographical regions. The degree of remoteness approach is often used by statistical agencies to define remoteness to develop policies to address the urban-rural divide. Examples of these include the OECD's (2011) Regional Typology and Australia's Remoteness Structure in the Australian Standard Geographical Classification (Australian Bureau of Statistics, 2011). Islands are often seen as remote areas, but this varies as well due to different levels of transport linkage and population self-sufficiency. Geographical typologies based on an island's geographic attributes have been made (Grydehøj, 2015a; Grydehøj et al., 2015; Källgard, 2005). There is also a typology in international maritime law to define island economic exclusive zones (Tanaka, 2006). However, this does not consider the connectivity and social attributes of island communities. Nevertheless, 
there has been significant progress in measuring island accessibility (Hernández Luis, 2002; Karampela et al., 2014; Makkonen et al., 2013) which opens up possibilities for analysis. It may be more helpful at present though to create a basic typology of island connectivity based on transport choice and modes (Table 2). We suggest it is possible to distinguish the 'evolution' of island communities by the level of connection in this manner.

This classification also seeks to incorporate the transitions that some islands have undergone due to new transport services and connections. For example, islands that were once only connected through ferry services have developed land-based modes. As a result, we seek to identify these changes and their contributions to social and economic changes on the island. The typology identified in Hong Kong is described further in the following sections.

Table 2: Island community connectivity typology in Hong Kong. (Source: Developed by the authors.)

\begin{tabular}{|l|l|l|l|l|}
\hline Code & $\begin{array}{l}\text { Island Community } \\
\text { Typology }\end{array}$ & $\begin{array}{l}\text { Transport Choice } \\
\text { Category }\end{array}$ & Transport Modes & $\begin{array}{l}\text { Examples in } \\
\text { Hong Kong }\end{array}$ \\
\hline NIC-Un & $\begin{array}{l}\text { Non-infrastructure- } \\
\text { connected island } \\
\text { (uninhabited) }\end{array}$ & Captive & $\begin{array}{l}\text { Ferry } \\
\text { (unscheduled) }\end{array}$ & $\begin{array}{l}\text { Green Island, Kau } \\
\text { Yi Chau, } \\
\text { Sunshine Island }\end{array}$ \\
\hline NIC-In & $\begin{array}{l}\text { Non-infrastructure- } \\
\text { connected island } \\
\text { (inhabited) }\end{array}$ & Captive & Ferry (scheduled) & $\begin{array}{l}\text { Lamma Island, } \\
\text { Cheung Chau, } \\
\text { Peng Chau }\end{array}$ \\
\hline FIC & $\begin{array}{l}\text { Fully infrastructure- } \\
\text { connected island }\end{array}$ & $\begin{array}{l}\text { Free choice (free } \\
\text { access to a variety } \\
\text { of modes) }\end{array}$ & $\begin{array}{l}\text { Car, MTR, bus, } \\
\text { ferry, minibus }\end{array}$ & $\begin{array}{l}\text { Hong Kong } \\
\text { Island, Tsing Yi, } \\
\text { Northern Lantau } \\
\text { (Tung Chung) }\end{array}$ \\
\hline RIC & $\begin{array}{l}\text { Restricted } \\
\text { connected island }\end{array}$ & $\begin{array}{l}\text { Semi-captive (No } \\
\text { other public } \\
\text { transport, limited } \\
\text { private vehicle } \\
\text { access) }\end{array}$ & $\begin{array}{l}\text { Ferry, in some } \\
\text { cases, bus and taxis } \\
\text { are available }\end{array}$ & $\begin{array}{l}\text { Discovery Bay, } \\
\text { Ma Wan, Mui } \\
\text { Wo }\end{array}$ \\
\hline L & $\begin{array}{l}\text { Lost island' } \\
\text { connected to } \\
\text { mainland by } \\
\text { reclamation }\end{array}$ & $\begin{array}{l}\text { Free choice (Free } \\
\text { access to a variety } \\
\text { of modes) }\end{array}$ & $\begin{array}{l}\text { Car, MTR, bus, } \\
\text { ferry, minibus }\end{array}$ & $\begin{array}{l}\text { Stonecutters } \\
\text { Island }\end{array}$ \\
\hline A & $\begin{array}{l}\text { Artificial Island } \\
\text { Free choice (Free } \\
\text { access to a variety } \\
\text { of modes) }\end{array}$ & $\begin{array}{l}\text { Car, MTR, bus, } \\
\text { ferry, minibus }\end{array}$ & $\begin{array}{l}\text { Chek Lap Kok } \\
\text { Airport Island, } \\
\text { Proposed Central } \\
\text { Waters Island }\end{array}$ \\
\hline
\end{tabular}

Non-infrastructure-connected (uninhabited) island communities (NIC-Un): These are islands with no fixed infrastructure connection. A distinction is made between islands with or without regular residents. Many of the uninhabited islands were populated in the past but experienced depopulation due to local economic decline (such as in fishing) and/or a lack of infrastructure (power, water, sewerage). Accessing these islands is often only possible by chartered boat services. Hong Kong has numerous such uninhabited islands, with the unofficial count standing at 107 (Wan, 2015). We do not discuss these islands in detail here due to their lack of permanent and sustainable populations.

Non-infrastructure-connected (inhabited) island communities (NIC-In): These are inhabited islands with no fixed links that are dependent on ferry transport. Sizable island communities are mostly served by regularly timetabled public ferry connections. These islands are often getaways for local and international tourists, offering a more rural and relaxed setting. Two islands in this typology are included in this study, namely Cheung Chau (Figure 2) and Lamma. 


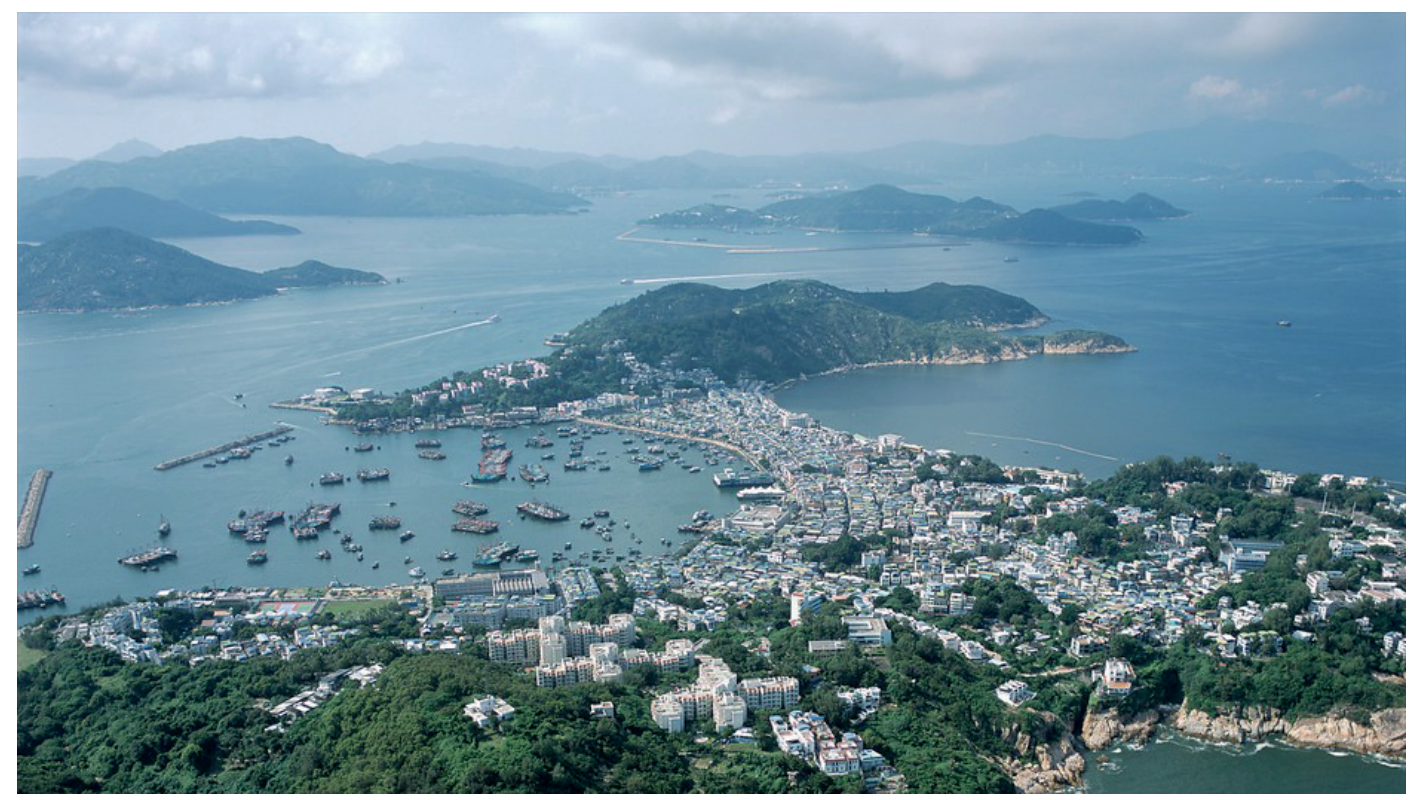

Figure 2: Cheung Chau Island which is currently isolated by sea and relies on ferry transportation. (Source: (C) Hong Kong Tourism Board)

Fully infrastructure-connected island communities (FIC): These islands are bounded by water on all sides but are now connected with one or more fixed links such as bridges or tunnels. Hong Kong Island, Tsing $\mathrm{Yi}$, and the pockets of island communities on Lantau Island are the key examples in this category (Figure 3). These islands have experienced rapid development and population growth within a few years after the completion of fixed infrastructures.

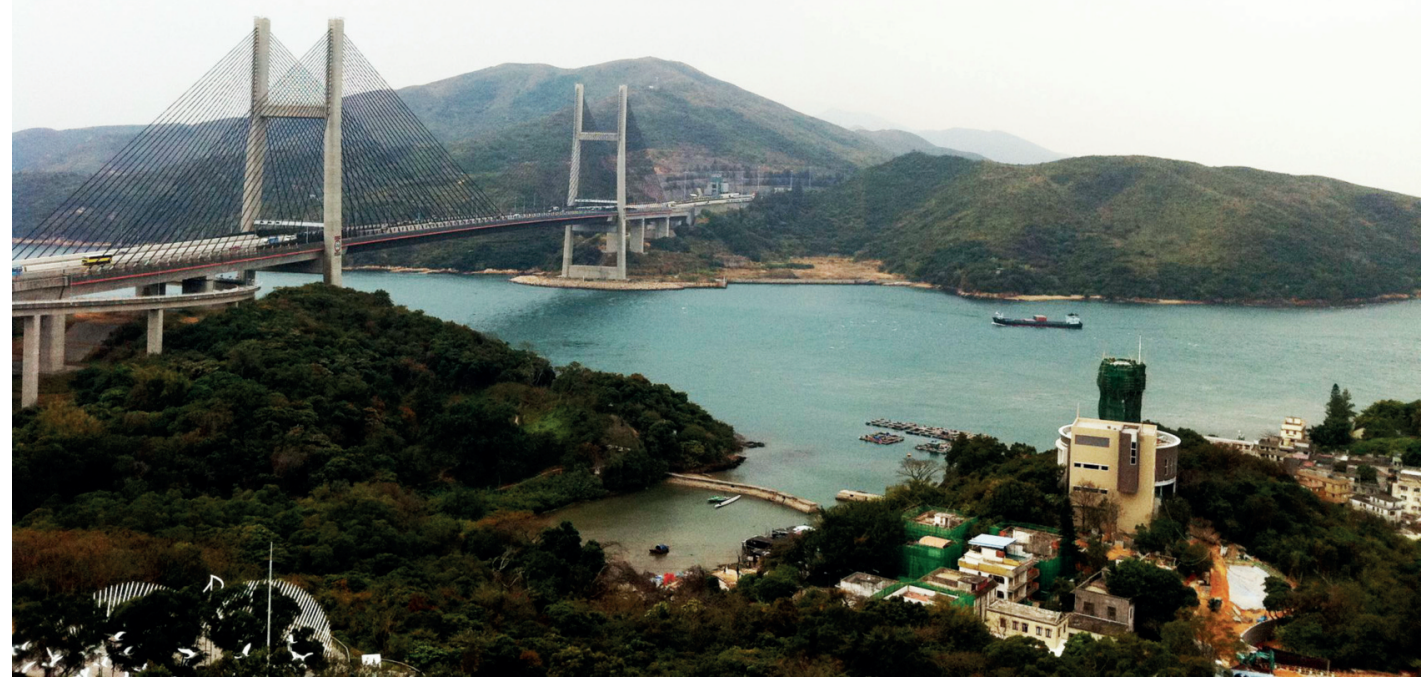

Figure 3: A series of bridges connect the peripheral islands of Lantau Island, Ma Wan, and TsingYi to the urban core of Kowloon and Hong Kong (Photo taken at MaWan). (Source: (C Abraham Leung)

Restricted infrastructure-connected island communities (RIC): These are special cases in Hong Kong which are island communities connected by a fixed link but with restrictions on household transport options put in place by the transport authority. Ma Wan (Figure 4) and Discovery Bay are examples of this type, where car ownership is heavily restricted and most residents are only able to choose public transport modes such as ferries, buses, or taxis. Mui Wo is another case as only taxis and vehicles owned by residents are allowed to enter the community by road due to limited infrastructure and traffic constraints. 


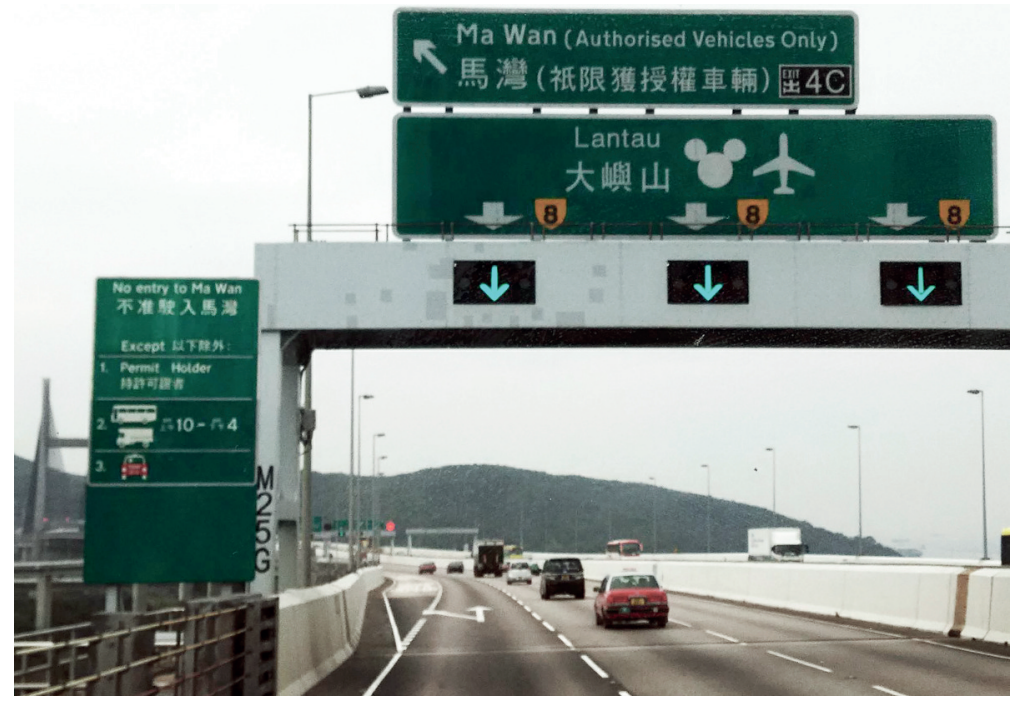

Figure 4: Although Ma Wan is connected by Tsing Ma Bridge, there is restricted access for private vehicles (Photo taken at before the highway ramp into Ma Wan). (Source: C C.S. Shui)

'Lost Islands' connected to mainland by reclamation $(L)$ : These are islands once separated from the mainland that are now contiguous with the mainland through artificial land creation. A notable example is Stonecutters Island which has been used as a military base by both British (before handover) and Chinese garrisons (after handover) in Hong Kong. In 1990 the island was connected to Kowloon by reclamation to provide land for the extension of Kwai Tsing Container Terminal and a centralised sewage treatment plant. This island does not have a permanent civilian population.

Artificial islands (A): These are islands that are substantially created from non-natural processes such as land filling or extensions from existing islands or reefs. Chek Lap Kok is an example as the majority of the island is formed by reclamation works. This can also be considered a fully infrastructure-connected island as it is connected to Lantau via fixed links.

Furthermore, the large-scale road Hong Kong-Zhuhai-Macau Bridge project across the Pearl River Delta is currently underway. This has led to further plans to develop Lantau, with proposals in place to resurrect the previous plan to link up Lantau and Hong Kong Island by artificial islands. Dubbed the 'East Lantau Metropolis', a number of artificial islands are proposed to be built in the waters around Kau Yi Chau and Hei Ling Chau (currently used for detention and corrective purposes) (Figure 5). At this stage, the Hong Kong administration's proposal is conceptual only and is under feasibility investigation. Nevertheless, it is included in the most recent territorial strategic plan for Hong Kong, the Hong Kong 2030 planning vision and strategy (Hong Kong Development Bureau, 2016b). The reclamation proposals in these waters are not, however, entirely new, as similar transport links and reclamation works were proposed to link Lantau to Kai Yi Chau for a new seaport under the Port and Airport Development Strategy (PADS) as far back as the early 1990s (Ure \& Wong, 1991). This project was delayed due to political tensions amid the uncertainty of the handover of Hong Kong back to China (Dimitriou \& Cook, 1998, p. 48) and ultimately scrapped due to dwindling growth in container throughput in Hong Kong as nearby mainland Chinese ports have developed, challenging Hong Kong's entrepôt role.

Nearby Macau is pushing for similar developments, dubbed the 'New Urban Zone', with artificial islands linked up by road and light-rail bridges. Toland (2017, p. 105) describes such processes as "anti-archipelago," an "undoing of the various archipelagic conditions that have existed, historically and topographically." In contrast, Sheng et al. (2017) regard the island cities of the Pearl River as "networked by nature and design: [...] lack of connectivity would occasion the demise of these places' distinctive urban island lifestyles and practices, not accentuate their islandness." We now turn to consider how these island types are populated and some of the issues these communities face. 


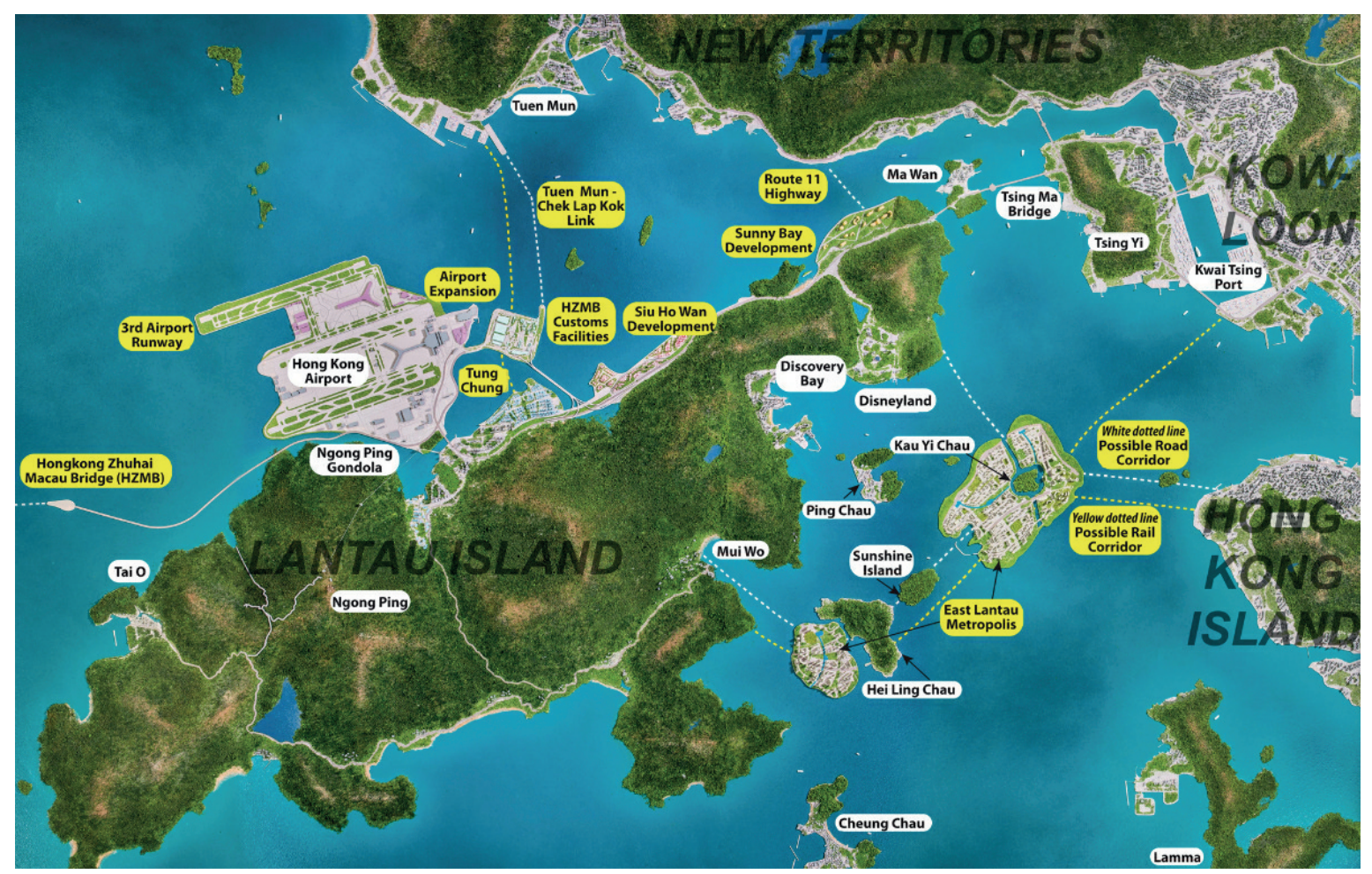

Figure 5: Annotated image from the Physical Model of Lantau Development Plan showing proposed future development plan of Lantau Island. Yellow labels denote future projects, whereas white labels are existing features. (Source: Reproduction and adaptation of the image permitted by the Director of Civil Engineering and Development, (C) Hong Kong SAR Government)

Table 3: Evolution of island communities in Hong Kong based on the typology and population.

\begin{tabular}{|c|c|c|c|c|c|c|c|c|c|}
\hline $\begin{array}{l}\text { Current } \\
\text { Typology } \\
\end{array}$ & NIC-Un & NIC-In & NIC-In & FIC & FIC & RIC & RIC & RIC & $A$ \\
\hline $\begin{array}{l}\text { Island } \\
\text { Comm. }\end{array}$ & $\begin{array}{l}\text { Kau Yi } \\
\text { Chau }\end{array}$ & \begin{tabular}{|l|}
$\begin{array}{l}\text { Cheung } \\
\text { Chau }\end{array}$ \\
\end{tabular} & \begin{tabular}{|l|} 
Lamma \\
Island
\end{tabular} & Tsing Yi & \begin{tabular}{|l} 
Tung \\
Chung
\end{tabular} & $\begin{array}{l}\text { Discovery } \\
\text { Bay }\end{array}$ & Ma Wan & Mui Wo & \begin{tabular}{|l} 
Chek Lap \\
Kok
\end{tabular} \\
\hline $\begin{array}{l}\text { Year of } \\
\text { Fixed Link } \\
\text { Connection }\end{array}$ & None & None & None & 1974 & 1997 & 1997 & 1997 & 1997 & 1997 \\
\hline $\begin{array}{l}\text { Type of } \\
\text { Fixed Link } \\
\text { Connection }\end{array}$ & $\mathrm{N} / \mathrm{A}$ & $\mathrm{N} / \mathrm{A}$ & $\mathrm{N} / \mathrm{A}$ & $\begin{array}{l}\text { road } \\
\text { bridges, } 1 \\
\text { rail bridge } \\
\end{array}$ & $\begin{array}{l}1 \text { bridge } \\
\text { (road }+ \\
\text { rail) }\end{array}$ & $\begin{array}{l}1 \text { bridge } \\
\text { (road) }\end{array}$ & $\begin{array}{l}1 \text { bridge } \\
\text { (road) }\end{array}$ & $\begin{array}{l}1 \text { bridge } \\
\text { (road) }\end{array}$ & $\begin{array}{l}1 \text { bridge } \\
\text { (road }+ \\
\text { rail) } \\
\end{array}$ \\
\hline $\begin{array}{l}\text { \# of Fixed } \\
\text { Links with } \\
\text { Hong Kong } \\
\text { proper }\end{array}$ & 0 & 0 & 0 & 5 & $1^{\star}$ & $1^{\star}$ & 1 & $1 \star$ & $1 \star$ \\
\hline Year & Pop. & & & & & & & & \\
\hline 1991 & 0 & 21,822 & 2,943 & 101,178 & 587 & 6,407 & 455 & 3,027 & 0 \\
\hline 1996 & 0 & 23,882 & 4,681 & 113,825 & 740 & 14,317 & 971 & 4,458 & 992 \\
\hline 2001 & 0 & 23,346 & 5,536 & 120,243 & 20,127 & 15,600 & 387 & 5,648 & 5 \\
\hline 2006 & 0 & 24,312 & 5,131 & 113,589 & 72,141 & 14,682 & 10,163 & 5,186 & 222 \\
\hline 2011 & 0 & 22,740 & 5,993 & 108,990 & 78,204 & 12,383 & 13,056 & 5,485 & 300 \\
\hline
\end{tabular}

*An additional connection from Lantau to Tuen Mun is being built as part of the Hong Kong-Zhuhai-Macau Bridge project, extending from Chek Lap Kok. This figure will increase to 2 once completed. (Source: Hong Kong Census 1991, 1996, 2001, 2006 and 2011, (C) Hong Kong Census and Statistics Department) 


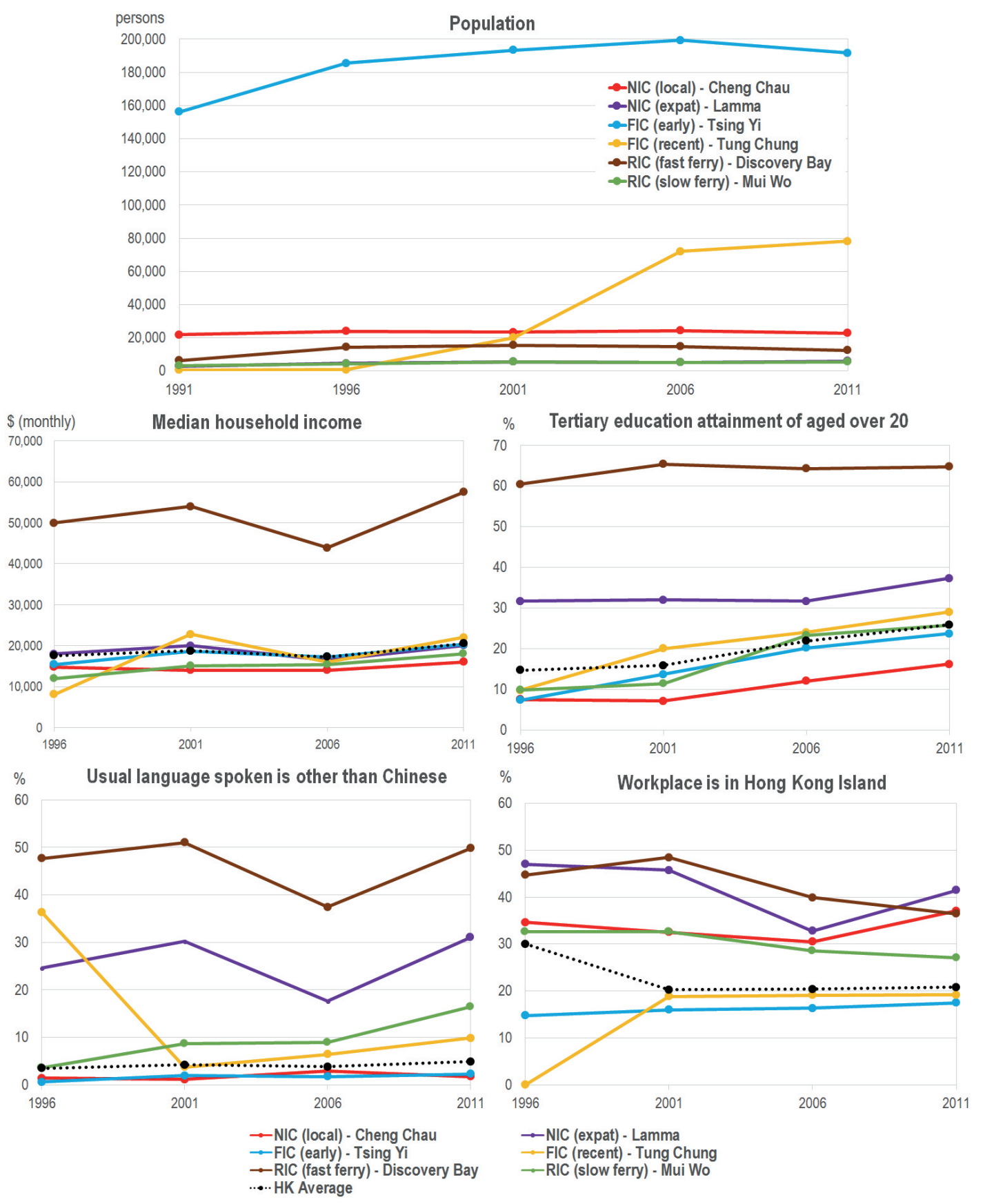

Figure 6: Evolution of selected island communities in Hong Kong. (Source: Hong Kong Census from 1999 to 2011, (C) Census and Statistics Department)

\section{Detailed analysis of selected island communities: population and transport data}

\section{Population Data}

Table 3 shows the population changes for those island community types, based on Hong Kong Census data for 1991 to 2011. More detailed population characteristics are compared to representative islands of the NIC, FIC, and RIC typologies. These include Cheung Chau and Lamma (NIC-In), Tsing Yi and Tung Chung (FIC), and Discovery Bay (RIC). These particular islands have been selected due to the availability of constant census data aggregation over the years.

Figure 6 shows that Hong Kong island communities with fixed link public transport infrastructure and no vehicular travel restrictions have seen rapid population growth. The Hong 
Kong context is slightly different to international examples where private vehicle modes are more dominant (Baldacchino, 2007; Kim, 2016). Discovery Bay was found to have very high levels of household income, due to its position as an affluent enclave with high levels of tertiary education. Language statistics for Lamma and Discovery Bay reflect both being popular areas for expatriates, with higher proportions of non-Chinese speakers. Overall, Hong Kong's tertiary attainment level has been increasing, but Cheung Chau has lagged behind and is the least socioeconomically advantaged island due to its relative isolation from Hong Kong Island, with jobs limited to the local economy, such as fishery and tourism. Cheung Chau is particularly isolated from the 'knowledge city' urbanisation (Glaeser \& Resseger, 2010) occurring in Hong Kong's centre. The peripheral island communities with better connections to the urban core are the most likely to have populations that are highly skilled, tertiary educated, and entrepreneurial in nature.

Commuting patterns of the different types of island communities are affected by available transport and employment options. Central Pier on Hong Kong Island acts as a hub for most of the outlying island ferry routes. NIC-In (Cheung Chau and Lamma Island) and RIC (Discovery Bay) residents are more likely to work on Hong Kong Island. Because ferries connect many of the outlying island communities, we turn now to look at ferry passenger numbers and levels of service.

Ferry service and passenger numbers data

The estimation of public transport frequency in Table 4 is based on a scoring system. Public transport operators' timetables or headways obtained from official websites served as data sources for the frequencies and service spans.

Table 4: Frequency (PTLOS) scores (Adapted from Pitot et al. (2006).

\begin{tabular}{|l|l|}
\hline Frequency (minutes) & Frequency Score \\
\hline Less than 5 & 6 \\
\hline 10 & 5 \\
\hline 15 & 4 \\
\hline 30 & 3 \\
\hline 60 & 2 \\
\hline More than 60 & 1 \\
\hline
\end{tabular}

To allow direct comparison of levels of service, a simple yet robust indexing method is used to estimate public transport level of service (PTLOS) based on frequency and service span. This method is based on the approach developed by Leung et al. (2015). The following equations are used for the PTLOS Index:

$$
\text { PTLOS = Average Frequency } \times \text { Effective Span of Service }
$$

Where:

$$
\text { Average Frequency }=\frac{\text { Peak Frequency Score } \times \text { Off Peak Frequency Score }}{2}
$$

and

$$
\text { Effective Span of Service }=\text { Hours of Service of each day }
$$

(Note: services with frequency less than two hours are not regarded as regular services.) 
Table 5: Trip time, level of service, and passenger numbers of key ferry services serving various island communities. (Source: Trip data are based on the ferry operators and transport department. Average ferry passenger numbers data is compiled from Hong Kong Legislative Council paper nos. CB(1)1556/03-04(03), CB(1)1648/09-10(04) and CB(4)831/15-16(03))

\begin{tabular}{|c|c|c|c|c|c|}
\hline \multirow[t]{2}{*}{ Route } & \multirow[t]{2}{*}{$\begin{array}{l}\text { Trip Time and } \\
\text { Fare }(2015)\end{array}$} & \multirow[t]{2}{*}{$\begin{array}{l}\text { PTLOS Score }^{\star} \\
(1-6)\end{array}$} & \multicolumn{3}{|c|}{$\begin{array}{l}\text { Average Daily Ferry } \\
\text { Passenger \# }\end{array}$} \\
\hline & & & 2009 & 2012 & 2015 \\
\hline \multicolumn{6}{|c|}{ Connections to Hong Kong Island or Kowloon (urban core) } \\
\hline \multicolumn{6}{|l|}{ to Cheung Chau (NIC-In) } \\
\hline Central-Cheung Chau & $\begin{array}{l}35-60 \text { minutes } \\
\text { HK\$ } 11.8-37.2 \\
\end{array}$ & 2.87 & 20458 & 23610 & 26315 \\
\hline \multicolumn{6}{|l|}{ to Lamma Island (NIC-In) } \\
\hline Central-Yung Shue Wan (Lamma Island) & $\begin{array}{l}27 \text { minutes } \\
\text { HK\$ } 14-19\end{array}$ & 1.98 & 7815 & 8601 & 9111 \\
\hline Central-Sok Kwu Wan (Lamma Island) & $\begin{array}{l}30-40 \text { minutes } \\
\mathrm{HK} \$ 17-24 \\
\end{array}$ & 0.64 & 997 & 1016 & 1257 \\
\hline $\begin{array}{l}\text { Aberdeen-Yung Shue Wan (Lamma } \\
\text { Island) via Pak Kok Tsuen }\end{array}$ & $\begin{array}{l}35 \text { minutes } \\
\mathrm{HK} \$ 19\end{array}$ & 0.73 & 749 & 771 & 845 \\
\hline \multirow[t]{2}{*}{$\begin{array}{l}\text { Aberdeen-Sok Kwu Wan (Lamma Island) } \\
\text { via Mo Tat (Lamma) }\end{array}$} & $\begin{array}{l}35 \text { minutes } \\
\mathrm{HK} \$ 12-18\end{array}$ & 0.75 & 523 & 553 & 642 \\
\hline & & & 10084 & 10941 & 11,855 \\
\hline \multicolumn{6}{|l|}{ to Tung Chung (FIC)* } \\
\hline $\begin{array}{l}\text { Tuen Mun-Tung Chung-Sha Lo Wan- } \\
\text { Tai O }\end{array}$ & $\begin{array}{l}50-90 \text { minutes } \\
\mathrm{HK} \$ 15-30\end{array}$ & 0.75 & 461 & 698 & 1102 \\
\hline \multicolumn{6}{|l|}{ to Discovery Bay (RIC) } \\
\hline Central-Discovery Bay & $\begin{array}{l}25 \text { minutes } \\
\mathrm{HK} \$ 40-57\end{array}$ & 2.71 & 12,122 & 11648 & 11707 \\
\hline \multicolumn{6}{|l|}{ Ma Wan (RIC) } \\
\hline Central-Ma Wan & $\begin{array}{l}22 \text { minutes } \\
\mathrm{HK} \$ 21.4-27\end{array}$ & 1.94 & 3,829 & 3376 & 3039 \\
\hline \multirow[t]{2}{*}{$\begin{array}{l}\text { Tsuen Wan-Ma Wan (Cancelled in 2012, } \\
\text { but resumed with limited services in 2013) }\end{array}$} & $\begin{array}{l}12 \text { minutes } \\
\mathrm{HK} \$ 10.2-12\end{array}$ & 0.04 & 4173 & Cancelled & 302 \\
\hline & & & 8002 & 3,376 & 3341 \\
\hline \multicolumn{6}{|l|}{ to Mui Wo (RIC) } \\
\hline Central-Mui Wo & $\begin{array}{l}35-55 \text { minutes } \\
\mathrm{HK} \$ 13.8-42.9\end{array}$ & 2.12 & 5828 & 5531 & 5865 \\
\hline \multicolumn{6}{|l|}{ Inter-Islands } \\
\hline $\begin{array}{l}\text { Peng Chau-Mui Wo-Chi Ma Wan- } \\
\text { Cheung Chau }\end{array}$ & $\begin{array}{l}\text { 49-55 minutes } \\
\mathrm{HK} \$ 11.4-12.8\end{array}$ & 0.75 & 985 & 915 & 1059 \\
\hline Discovery Bay-Mui Wo & $\begin{array}{l}20 \text { minutes } \\
\$ 12-\$ 15\end{array}$ & 0.10 & 276 & No Data & 264 \\
\hline \multicolumn{3}{|l|}{ Total } & 58216 & 56719 & 61508 \\
\hline
\end{tabular}

* For reference, the Level of Service Score for MTR rail Tung Chung Line servicing Hong Kong Island to Tung Chung in Lantau Island is 4 out of 6.

\# The ferry passenger numbers listed in the tables include only franchised and licensed services with a scheduled timetable. Other services such as water taxi and charter operations are not included. 
A combined assessment of ferry routes based on trip time, fare, and frequency levels (PTLOS) compared to average daily ferry passenger numbers is provided in Table 5. Only the data from 2009 to 2015 is shown as previous ferry passenger numbers covering all these islands is not currently available. Some islands, such as MaWan, which is not shown in Figure 6, are included in Table 5. Generally, ferry passenger numbers are higher for routes without direct competition from fixed links, shorter trip times, and higher levels of service. Discovery Bay (RIC) retained reasonable ferry passenger numbers despite competition from fixed link connections. This is largely due to frequent, direct, and speedy ferry services to Central on Hong Kong Island. Most of the day, and especially in peak hours, this ferry route is faster and more comfortable than other public transport modes, despite its higher fare prices. The ferry route connecting Tung Chung, the FIC next to the airport, to Tuen Mun, a new town at Hong Kong's northwest periphery, well away from the territory's urban core has increased passenger numbers, but numbers remain very low when compared to other ferry services. A fixed road link is also under construction, which will likely spell the end of this ferry route. For Ma Wan (RIC), ferry passenger numbers to nearby Tsuen Wan dried up due to competition from bus services via the Tsing Ma Bridge, and the service was cancelled in 2012. Due to complaints by the residents, it reopened in 2013 to provide three round trips per day only (Tsuen Wan District Council, 2013).

Hong Kong's numerous outlying islands have experienced mixed fortunes: NIC-Ins had populations remaining stagnant, whereas FICs experienced rapid growth. Yet NIC-Ins are also attracting certain demographics, such as foreign expatriates and local residents who value lower densities and sea views at the expense of travel cost and time. The levels of service of ferries are also important since direct, frequent trips to major employment centres are commercially viable with sizeable passenger numbers. Discovery Bay shows the potential for FOD in the Hong Kong context, but this example is not being replicated elsewhere in the territory.

\section{Rethinking the role of ferries}

The demise of ferry transport in Hong Kong is largely due to competition with fixed link connections to islands, reclamation, and pier relocation, compounded by a lack of government support. There has been a visible shift in Hong Kong's transport policy, which has progressed from a focus on inter-modal coordination in the late 1980s and early 1990s (Hong Kong Government, 1990) to a 'rail as backbone' policy from the early 2010s (Hong Kong Transport and Housing Bureau, 2014). Since the late 1990s, ferries have largely been seen as only viable for "essential services for the outlying islands and to supplement other modes in the inner harbour" (Hong Kong Transport Department, 1999). We see little conceptualisation of alternative ferry systems or route structures, or the potentials of FOD as a transformative development agenda for the city. This is in part hamstrung by existing operating models and much of the current fleet, which has failed to be modernised in line with other transport modes.

Franchised bus and ferry services often operate on the basis of cross-route subsidy, where the government will allow a particular operator exclusive access to profitable routes in exchange for servicing unprofitable ones (Wang \& Lo, 2008). However, with more fixed links and railways being built, the franchise policy has become increasingly unworkable and costly for ferry operators. Since the demise of the largest ferry operator, the Hongkong and Yaumatei Ferry (HYF), a company with bus operations (New World First) has taken over most of its routes. Current ferry operators tend to run on a short-term licence system, with limited rights to ply a route, instead of the longer-term franchises previously favoured; the licence system is seen as better able to respond to market conditions and operational cost fluctuations (e.g. oil prices) (Kwan, 1999). Although it is government policy not to provide direct subsidy or financial assistance to ferry operators, a form a proxy subsidy is provided for the key struggling ferry routes serving NICs or RICs so as to ensure accessibility in outlying island communities without fixed links. Subsidies are provided through payments for vessel maintenance; exemptions from charges for safety 
inspections, water supply, and land rent; and payments for concession (elderly and children) tickets. Without such measures, the existing ferry operators could not survive at current fare levels. These piecemeal assistance measures, however, do not help ferry operators become more innovative or responsive to market trends in order to demonstrate the value of ferry services, effectively compete with fixed links, and offer another viable transport option.

Furthermore, under the current fare adjustment mechanism, public transport fares are regulated, which makes fare increases difficult. Under these conditions, ferries have enough trouble providing existing services, let alone investing in better ferries or operations (e.g. more fuel efficient or faster services). While non-ferry operational revenue, such as advertising and retail/food revenue near piers, may support ferry operations, these often amount too little. All this raises doubt as to the viability of outlying island ferry routes, and such uncertainties often encourage disinvestment in ferry services (Thompson et al., 2006, p. 33). Hong Kong's transport-only focus on ferry operations is in stark contrast to the FOD model being pursued elsewhere. We look now to how other cities use ferries to stimulate land development and the factors underpinning their success, to suggest what might be possible for Hong Kong.

\section{1) Speed and level of service}

International experience has shown that high-speed services and good frequency are important for maintaining public transport passenger numbers (Walker, 2012). Studying commuters on ferries, Soumoy and Sweeny (2000) find speed to be one of the most important service elements. A model of smaller, faster vessels at higher frequency has been shown to be more effective in London and Brisbane, resulting in rapid growth in commuter journeys (Tanko \& Burke, 2016). The current ferry network in Hong Kong consists of a central core hub and periphery spoke-type network (a notion coined by Baldacchino and Ferreira (2013)). Elsewhere, there is a trend to provide faster and more frequent linear ferry services, parallel with the shoreline, that run like river-buses, providing cross-river/harbour and multi-stop routes, as seen on the East River New York, Brisbane, Bangkok Venice, and Copenhagen. Linear routes were recommended in the Metroplan Stage II Review (Hong Kong Planning Department, 2003), which proposed ferry services connecting future tourism nodes at Kai Tak and West Kowloon Cultural District. Perhaps an even larger, bi-directional circular route serving the key destinations at the urban core of Kowloon and Hong Kong Island and the outlying islands in a linear form, replacing the infrequent hub-and-spoke network, could be an option for providing higher frequency services which are more useful to residents and visitors.

Ferries are also promoted elsewhere as having greater amenity values and opportunities to work on-board than buses or packed mass transit services with excellent on-time running, a smooth ride, and time spent in the natural environment. This is increasingly relevant, as comfort of commute has been found to be a significant contributor to mode choice (Jain \& Lyons, 2008; Lyons et al., 2013; Mokhtarian \& Salomon, 2001). An Australian study finds value of travel time aboard ferries to be higher (Douglas \& Wallis, 2013), possibly due to less crowded conditions, better passenger comfort, and better scenery during ferry rides. There are indications that passengers are willing to travel on a longer, less direct ferry route instead of a more direct bus route.

Whether ferry modernisation to improve speed and service quality can succeed in Hong Kong is still unknown and untested. Yet comparing Hong Kong with other cities requires careful consideration. For instance, Hong Kong's harbour is wider and more prone to wave disruptions than those of many other cities. It also still accommodates a large amount of harbour traffic, whereas other cities have largely shifted such port activities from urban areas to downriver fringe locations (Baird, 1996, pp. 146-150). It should also be noted that while Brisbane's CityCat service can travel at 25 knots, there is a speed limit between 8 to 15 knots in Victoria Harbour (Hong Kong Marine Department, 2000). With such restrictions, it might be difficult to develop a case for improving Hong Kong's ferries. Perhaps a change in marine transport policy and technological investment could revive the territory's ferry services. 


\section{2) Ease of transfer to other modes and the network effect}

Another factor in overall public transport success is the ease of inter-modal transfer, which can achieve network effects, allowing a user to go to anywhere in the network with minimal time and monetary cost (Curtis \& Scheurer, 2010; Dodson et al., 2011). In the case of Hong Kong, however, while there has been headway in connecting with other modes, ferry services have failed to sustain passenger numbers mostly due to unattractive waterfront land uses and limited interchange opportunities at existing ferry piers. As in other cities such as Bangkok, ferry transport has been largely omitted from the discussion of centralised transport network planning. New ferry operations such as Shanghai's 'River Bus' (Lan, 2016) and Taipei's 'Blue Highway' project (Hsiao et al., 2015) have failed in part due to their exclusion from wider land use planning as well as fare and transport integration. In Hong Kong, ferry passenger numbers are largely dependent on demand from a catchment area within walking distance to the ferry piers, feeder buses, and activity centres, yet there has long been a shortage of piers at prime locations (Wong, 1998). Reclamation works in Victoria Harbour in the last decade have made piers even more distant from activity centres, which has likely reduced the appeal of ferry services. Efforts to revitalise the harbourfront and to provide direct and convenient feeder bus or rail services to ferries remain slow. Public transport modes tend to compete against each other in Hong Kong, rather than working together. Better links with buses would be particularly beneficial as Ceder (2006) shows that a significant number of Hong Kong ferry users (59-80\% depending on island category) also use other modes as part of their journey. Hong Kong has recently recognised this and is providing transfer discounts for changing between ferry and rail for a limited period (MTR Corporation, 2014). Such discounts could be made permanent and be expanded to buses and other modes to improve the attractiveness of multi-modal journeys.

\section{3) Ferry oriented development (FOD)}

Locating residential or commercial development near piers has been shown to be an effective way of boosting ferry passenger numbers. In Brisbane and Gothenburg, key waterfront urban developments are coordinated with new dedicated ferry services as a form of FOD. In these areas, development arrangements are negotiated whereby developers pay for ferry terminal infrastructure for the right to have a ferry stop service their development. In Brisbane, this policy is officially supported in transport plans (Brisbane City Council, 2008, p. 25). In London, developers have subsidised routes to stops that would be unviable for the private operators to run themselves. For example, the O2 Arena at North Greenwich is serviced in this manner (Fox, 2016). In some cases, developers have paid to construct ferry piers such as the Regatta Pier in Brisbane and Plantation Wharf in London as a way to capture the effect of property value uplift of ferry terminals and services. Property value uplift from urban ferry systems has been demonstrated in both New York (New York City Economic Development Corporation, 2013) and Brisbane (Tsai et al., 2015). These studies reveal significant value uplift (around 4\%-8\%) within $400 \mathrm{~m}$ of a ferry terminal. At the same time, Hong Kong is actually practising property value-capture in rail in the form of TODs (Cheung, 2011; Loo et al., 2010), but dedicated FODs at piers remain few. In the mid-1990s, a proposal was mooted to allow the Hongkong and Yaumati Ferry Company to develop a FOD project above the current Central piers. This plan was derailed by the Asian Financial Crisis in 1997 and a resultant dispute regarding land premium charges. This might have caused the demise of Hongkong and Yaumati Ferry Company's services in 2000.

The successes of New York, Gothenburg, and Brisbane could be a catalyst for rethinking Hong Kong waterfront development planning and means of lifting ferry passenger numbers. There are nevertheless a number of outer-urban FODs in Hong Kong, such as at the car-prohibited RICs of Ma Wan and Discovery Bay. This represents a workable model in niche settings. Governance issues may help explain why FOD is not proliferating across Hong Kong's more urbanised areas. Earlier, the Harbour Commission was established in the wake of public protests against further reclamation inVictoria Harbour and the demolition of the historic Queen's 
Pier and Star Pier. The terms of reference of this Commission, however, only narrowly focused on urban design and land use development aspects and are limited to the defined areas of Victoria Harbour; transport is not explicitly mentioned (Harbourfront Commission, 2013). Ferry-related policies are largely regulated by the Transport and Housing Bureau and Transport Department. This arrangement might have resulted in limited scope, preventing discussion of possible ferry options. In other cities, public interest in ferries and their recognised importance have spurred the development of dedicated ferry policies with FOD as part of their remit, as seen in Sydney, London, and New York.

\section{4) Dedicated ferry strategies}

Sydney's ferry future: Modernising Sydney's Ferries (NSW Government, 2013) is a 20-year plan aiming to modernise Sydney's ageing fleet, restore ferry frequency and coverage, and develop the future Barangaroo Ferry Hub connecting Sydney Harbour and the Parramatta River. Transport for London's (2013) River Action Plan proposes marketing and land-use measures to further develop the city's linear ferry system along the River Thames, with a target of 12 million river journeys a year by 2020, up from the current 9 million. NewYork City has recently invested in a five-borough, city-wide ferry system in New York Harbour and the surrounding estuaries, with the City Wide Ferry initiative pushed by current New York Mayor Bill de Blasio (New York City Economic Development Corporation, 2011, 2013).

The upcoming Hong Kong 2030+ strategic plan emphasises the construction of fixed links and artificial islands, but there is some possibility for ferries and FOD. The government's public consultation proposal has stated that "new ferry services could be explored as an alternative transport mode" (Hong Kong Development Bureau, 2016a, p. 15), though no further details have yet been given. The current debate centres on island connectivity and use of land or water-based transport. Regardless of which method is chosen to connect these new island communities, it will be necessary to plan and invest to ensure adequate access and minimise chances of social exclusion. It is unclear to what extent this be planned and what role fixed links or water transport will play. In terms of the relative cost and flexibility of such services, ferries could be considered first, before proposals to construct environmentally and financially costly fixed links. Small trials, such as those New York ran in the East River before investing in its City-Wide Ferry Services, represent a possible pathway for prudent experimentation. There may also be other opportunities beyond scheduled services. Communities have also suggested the reintroduction of water-taxi type ferries (locally known as wallas wallas) to help reactivate the harbour (DeWolf, 2017).

\section{Concluding remarks}

The paper has made a number of contributions to the literature, including a new typology of island communities based on the existence or absence of fixed links. This is a theoretical contribution for urban island studies, and this typology could be expanded to other similar cities which are water separated and connected by either ferries or fixed links. The paper makes applied contributions in showing the evolution of Hong Kong's island development in comparison to an alternative scenario involving FOD, as used in New York and London, and in providing a useful overview of ferry operations and performance in Hong Kong. The key policy implication is the necessity of re-evaluating the role of ferries in Hong Kong, the possibilities of FOD, and at least considering the merits of establishing a more coherent long-term ferry strategy.

The findings may be particularly relevant for nearby Sinophone cities (including other island cities) with similar geography, albeit with different regulatory frameworks for urban development. One limitation of this study was the inability to analyse the different island communities in greater detail due to data availability constraints. This may be possible with future research, by exploring if and how the situation has changed with the upcoming release of Census 2016 data in Hong Kong. Exploring 
further the value of specific FOD strategies, perhaps comparing various waterfront cities, could provide policymakers with evidentiary support for alternative transport and land use planning options, including the costs and benefits of sustainable outlying island communities, and enhancing knowledge of how ferries might help maintain islands' social, leisure, and cultural values.

\section{Acknowledgements}

We thank Gui Lohmann of Griffith University (Australia) and Timo Eccarius of National Chiao Tung University (Taiwan), in providing valuable comments to the early versions of the manuscript of this paper. Abraham Leung and Michael Tanko are the recipients of Australian Government Research Training Program Scholarships and Endeavour Research Fellowships. Matthew Burke was a recipient of an Australian Research Council Future Fellowship (FT120100976).

\section{References}

Abercrombie, P. (1948). Hong Kong preliminary planning report. Hong Kong: Hong Kong Government Printer.

Australian Bureau of Statistics. (2011). Australian statistical geography standard (ASGS): Volume 5 remoteness structure. Canberra: Australian Bureau of Statistics.

Baird, A.J. (1996). Containerization and the decline of the upstream urban port in Europe. Maritime Policy \& Management, 23(2), 145-156. https://doi.org/10.1080/03088839600000071

Baird, A. J., \& Pedersen, R. N. (2013). Analysis of CO2 emissions for island ferry services. Journal of Transport Geography, 32, 77--85. https://doi.org/10.1016/j.jtrangeo.2013.08.007

Baldacchino, G. (2007). Fixed links and the engagement of islandness: reviewing the impact of the Confederation Bridge. Canadian Geographer / Le Géographe Canadien, 51(3), 323-336. https://doi.org/10.1111/j.1541-0064.2007.00181.x

Baldacchino, G., \& Ferreira, E.C.D. (2013). Competing notions of diversity in archipelago tourism: transport logistics, official rhetoric and inter-island rivalry in the Azores. Island Studies Journal, 8(1), 84-104.

Barter, P. (2007). 'Central' Singapore Island, 'peripheral' mainland Johor: making the link. In G. Baldacchino (Ed.), Bridging islands: the impact of fixed links. Charlottetown: Acorn.

Becken, S. (2002). Tourism and transport in New Zealand: implications for energy use. Lincoln, NZ: Lincoln University.

Brisbane City Council. (2008). Transport plan for Brisbane 2008-2026. Brisbane: Brisbane City Council.

Calderwood, E., \& Freathy, P. (2011). Challenges in the supply of perishable products to island communities. The International Review of Retail, Distribution and Consumer Research, 21(2), 145-160. https://doi.org/10.1080/09593969.2011.562679

Ceder, A. (Avi). (2006). Planning and evaluation of passenger ferry service in Hong Kong. Transportation, 33(2), 133-152. https://doi.org/10.1007/s11116-005-3047-1

Cervero, R. (2004). Transit-oriented development in the United States: experiences, challenges, and prospects. Washington, D.C: Transportation Research Board.

Cheung, C. (2011). TOD and travel behavior in Hong Kong: a study on the effectiveness and better usage of the current railway system MTR. Hong Kong: University of Hong Kong. Retrieved from http://hdl.handle.net/10722/144206

Cottrell, W.D. (2011). Comparison of ferry boat and highway bridge energy use. Energies, 4(12), 239-253. https://doi.org/10.3390/en4020239

Curtis, C., \& Scheurer, J. (2010). Planning for sustainable accessibility: developing tools to aid discussion and decision-making. Progress in Planning, 74(2), 53-106. https://doi.org/10.1016/j.progress.2010.05.001

DeWolf, C. (2017). Waterworld: a short History of ferries, kaitos and walla-wallas in Hong Kong. Zolima Citymag, 1 June. Retrieved from https://zolimacitymag.com/waterworld-shorthistory-of-ferry-kaito-and-walla-walla-in-hong-kong 
Dimitriou, H.T., \& Cook, A. (Eds.). (1998). Land-use/transport planning in Hong Kong: the end of an era: a review of principles and practices. Aldershot \& Brookfield: Ashgate.

Dodson, J., Mees, P., Stone, J., \& Burke, M. (2011). The principles of public transport network planning: a review of the emerging literature with select examples. Brisbane: Urban Research Program, Griffith University.

Douglas, N., \& Wallis, I. (2013). Predicting the value of public transport in-vehicle time. Australasian Transport Research Forum 2013 Proceedings. Brisbane: Australasian Transport Research Forum.

Eichhorn, M.P. (2016). Life on islands. In Natural systems: the organisation of life (pp. 303-322).

Chichester: John Wiley \& Sons. https://doi.org/10.1002/9781118905982.ch19

Fox, T. (2016). Different approaches to public/private ferry partnerships for urban waterborne transportation systems. Presented at the Interferry Conference 2016, Manila. Retrieved from http://www.interferry.com/conference/2016-conference-papers/

Glaeser, E.L., \& Resseger, M.G. (2010). The complementarity between cities and skills. Journal of Regional Science, 50(1), 221-244. https://doi.org/10.1111/j.1467-9787.2009.00635.x

Grydehøj, A. (2015a). Island city formation and urban island studies. Area, 47(4), 429-435. https://doi.org/10.1111/area.12207

Grydehøj, A. (2015b). Making ground, losing space: land reclamation and urban public space in island cities. Urban Island Studies, 1, 96-117. https://doi.org/10.20958/uis.2015.6

Grydehøj, A., Pinya, X. B., Cooke, G., Doratlı, N., Elewa, A., Kelman, I., Pugh, J., Schick, L., Swaminathan, R. (2015). Returning from the horizon: introducing urban island studies.

Urban Island Studies, 1, 1-19. https://doi.org/10.20958/uis.2015.1

Harbourfront Commission. (2013). Terms of reference of the Harbourfront Commission. Retrieved from http://www.hfc.org.hk/en/terms of reference/

Hay, P. (2006). A phenomenology of islands. Island Studies Journal, 1(1), 19-42.

Hernández Luis, J.Á.H. (2002). Temporal accessibility in archipelagos: inter-island shipping in the Canary Islands. Journal of Transport Geography, 10(3), 231-239. https://doi.org/10.1016/S0966-6923(02)00014-5

Hong Kong Crown Lands and Survey Office (1966). Colony Outline Plan - Book 1. Hong Kong: Hong Kong Government Printer.

Hong Kong Development Bureau (2016a). Towards a planning vision and strategy transcending 2030 - preliminary concepts for the East Lantau Metropolis. Hong Kong: Hong Kong Government. Hong Kong Development Bureau (2016b). Towards a planning vision and strategy transcending 2030 - public engagement booklet. Hong Kong: Hong Kong Government.

Hong Kong Government (1990). Moving into the 21st Century: the white paper on transport policy in Hong Kong. Hong Kong: Hong Kong Government Printer.

Hong Kong Government (2013). The 2013 policy address: seek change maintain stability serve the people with pragmatism. Hong Kong: Hong Kong Government Printer.

Hong Kong Legislative Council (2016). Submission: green groups' joint request for substantiation of the conservation plan for Lantau. Retrieved from http://www.legco.gov.hk/yr1516/english/panels/dev/papers/dev20160416cb1-800-11-e.pdf

Hong Kong Marine Department (2000). Marine Department notice no. 84 of 2000. Retrieved from https://web.archive.org/web/20060319100032/http://www.mardep.gov.hk/en/notices/pdf/mdn00084.pdf

Hong Kong Planning Department (2003). Option formulation and evaluation. In Stage II study on review of Metroplan and the related Kowloon Density Study Review final report. Retrieved from http://www.pland.gov.hk/pland en/p study/comp s/metroplan/metro finalreport/ch20.htm

Hong Kong Transport and Housing Bureau (2014). Railway Development Strategy 2014. Hong Kong: Transport and Housing Bureau.

Hong Kong Transport Department (1991). Recommendation of cross harbour public transport services - no. 3. Hong Kong: Hong Kong Government Printer.

Hong Kong Transport Department (1999). The third comprehensive transport study. Hong Kong: Hong Kong Government. 
Hsiao, T.-F., Guo, Y., Lu, H.-C., \& You, B.-R. (2015). Mayor Ma wasted 250 million on river sludge dredging works (Taipei City) (Blue Highway). Liberty Times Net. Retrieved from http://news.ltn.com.tw/news/local/paper/894731

Hughes, R. (1976). Borrowed place, borrowed time: Hong Kong and its many faces (2nd revised ed). London: Deutsch.

Jain, J., \& Lyons, G. (2008). The gift of travel time. Journal of Transport Geography, 16(2), 81-89. https://doi.org/10.1016/j.jtrangeo.2007.05.001

Källgard, A. (2005). Fact sheet: the islands of Sweden. Geografiska Annaler, Series B: Human Geography, 87(4), 295-298. https://doi.org/10.1111/j.0435-3684.2005.00200.x

Kamen, P., \& Barry, C.D. (2011). Urban passenger-only ferry systems: issues, opportunities and technologies. In R. Delpizzo, H. Wang, \& A. Panek (Eds.) Sustainability in the maritime industry: a collection of relevant papers. New York: Society of Naval Architects and Marine Engineers.

Karampela, S., Kizos, T., \& Spilanis, I. (2014). Accessibility of islands: towards a new geography based on transportation modes and choices. Island Studies Journal, 9(2), 293-306.

Kim, J.-E. (2016). Land use patterns and landscape structures on the islands in Jeonnam Province's Shinan County occasioned by the construction of mainland bridges. Journal of Marine and Island Cultures, 5(1), 53-59. https://doi.org/10.1016/j.imic.2016.05.007

Knowles, R. (2000). The Great Belt fixed link and Denmark's transition from interisland sea to land transport. Geography, 85(4), 345-354.

Knowles, R. (1996). Fixed links and short sea crossings. In B.S. Hoyle (Ed.), Cityports, coastal zones, and regional change: international perspectives on planning and management. Chichester: Wiley.

$\mathrm{Ku}$, A.S. (2012). Remaking places and fashioning an opposition discourse: struggle over the Star Ferry pier and the Queen's pier in Hong Kong. Environment and Planning D: Society and Space, 30(1), 5-22. https://doi.org/10.1068/d16409

Kwan, C., Rachel. (1999). A study of the death of franchise policy for ferry services in Hong Kong. Masters Dissertation. Hong Kong: University of Hong Kong.

Lai, L. W.-C. (1999). Reflections on the Abercrombie Report 1948: a strategic plan for colonial Hong Kong. The Town Planning Review, 70(1), 61-87. https://doi.org/10.3828/tpr.70.1.w75372571644r760

Lan, Y. (2016). Lack of patronage closes Shanghai's river waterbus service. Global Times, 31 March. Retrieved from http://www.globaltimes.cn/content/976824.shtml

Lantau Development Advisory Committee. (2016). Lantau - Space for All - First-term Work Report. Hong Kong: Lantau Development Advisory Committee.

Le Pichon, A. (Ed.). (2006). China trade and empire: Jardine, Matheson \& Co. and the origins of British rule in Hong Kong, 1827-1843. Oxford; New York: Published for the British Academy by Oxford University Press.

Leung, A., Burke, M., \& Cui, J. (2016). The tale of two (very different) cities - Mapping Urban Transport Oil Vulnerability of Brisbane and Hong Kong. Presented at the 14th World Conference on Transport Research 2016, Shanghai, China.

Loo, B. P.Y., Chen, C., \& Chan, E.T.H. (2010). Rail-based transit-oriented development: Lessons from New York City and Hong Kong. Landscape and Urban Planning, 97(3), 202-212. https://doi.org/10.1016/j.landurbplan.2010.06.002

Loo, B.P.Y., \& Chow, A.S.Y. (2011). Jobs-housing balance in an era of population decentralization: an analytical framework and a case study. Journal of Transport Geography, 19(4), 552-562. https://doi.org/10.1016/j.jtrangeo.2010.06.004

Lyons, G., Jain, J., Susilo, Y., \& Atkins, S. (2013). Comparing rail passengers' travel time use in Great Britain between 2004 and 2010. Mobilities, 8(4), 560-579. https://doi.org/10.1080/17450101.2012.743221

Makkonen, T., Salonen, M., \& Kajander, S. (2013). Island accessibility challenges: rural transport in the Finnish archipelago. European Journal of Transport and Infrastructure Research, 13(4), 274-290. 
Moirangthem, K., \& Baxter, D. (2016). Alternative Fuels for marine and inland waterways. Petten: European Union.

Mokhtarian, P.L., \& Salomon, I. (2001). How derived is the demand for travel? Some conceptual and measurement considerations. Transportation Research Part A: Policy and Practice, 35(8), 695-719. https://doi.org/10.1016/S0965-8564(00)00013-6

MTR Corporation. (2014). Fresh off the ferry? Save $\$ 1.5$ on the MTR! Retrieved from http://www.mtr.com.hk/en/customer/main/interchange ferries.html

Murray, A.T., \& Davis, R. (2001). Equity in regional service provision. Journal of Regional Science, 41(4), 557-600. https://doi.org/10.1111/0022-4146.00233

New York City Economic Development Corporation (2013). Citywide ferry study 2013. New York: New York City Economic Development Corporation.

New York City Economic Development Corporation (2011). Comprehensive citywide ferry study 2011. New York: New York City Economic Development Corporation.

Newman, P., \& Kenworthy, J. (2011). Evaluating the transport sector's contribution to greenhouse gas emissions and energy consumption. In R. Salter, S. Dhar, \& P. Newman (Eds.), Technologies for climate change mitigation - transport sector. Frederiksberg \& Roskilde: UNEP Risø Centre on Energy, Climate and Sustainability.

$\mathrm{Ng}$, M.K. (2006). World-city formation under an executive-led government: the politics of harbour reclamation in Hong Kong. The Town Planning Review, 77(3), 311-337. https://doi.org/10.3828/tpr.77.3.4

Ng, M.K., \& Cook, A. (1997). Reclamation: an urban development strategy under fire. Land Use Policy, 14(1), 5-23. https://doi.org/10.1016/S0264-8377(96)00028-2

NSW Government. (2013). Sydney's ferry future - Modernising Sydney's ferries. Sydney: New South Wales Government. Retrieved from http://www.transport.nsw.gov.au/sydneys-ferryfuture-modernising-sydneys-ferries

OECD (2011). Defining and describing regions. In OECD Regions at a Glance 2011. Paris: OECD. https://doi.org/10.1787/reg_glance-2011-4-en

Pang, M.D. (2001). An evaluation of waterborne ferry services in Hong Kong: past $\mathcal{E}$ future. Bachelors Dissertation. Hong Kong: University of Hong Kong.

Pigou-Dennis, E., \& Grydehøj, A. (2014). Accidental and ideal island cities: islanding processes and urban design in Belize City and the urban archipelagos of Europe. Island Studies Journal, 9(2), 259-276.

Pitot, M., Yigitcanlar, T., Sipe, N., \& Evans, R. (2006). Land use \& public transport accessibility index (LUPTAI) tool - the development and pilot application of LUPTAI for the Gold Coast. In ATRF06 Forum Papers. State of Queensland.

Scottish Parliament (2017). Islands (Scotland) bill (draft). Edinburgh: Scottish Parliament. UK. Retrieved from http://www.parliament.scot/parliamentarybusiness/Bills/105168.aspx

Sheng, N., Tang, U.W., \& Grydehøj, A. (2017). Urban morphology and urban fragmentation in Macau, China: island city development in the Pearl River Delta megacity region. Island Studies Journal, 12(2). https://doi.org/10.24043/isj.25

Sipe, N., \& Burke, M. (2011). Can river ferries deliver smart growth?: experience of CityCats in Brisbane, Australia. Transportation Research Record, 2217, 79-86. https://doi.org/10.3141/2217-10

Soumoy, P., \& Sweeny, T. (2000). Effects of enhanced ferry service on Golden Gate corridor transportation: from Dromedary to Camel: How MV inverted the ferry ridership curve. Transportation Research Record, 1704, 100-104. https://doi.org/10.3141/1704-13

Stenius, I., Garme, K., Kihl, S.H., \& Burman, M. (2014). WATERWAY 365: system analysis of challenges in increased urban mobility by utilization of the water ways. Stockholm: KTH Centre for Naval Architecture.

Swaminathan, R. (2015). Ports and digital ports:the narrative construction and social imaginaries of the island city of Mumbai. Urban Island Studies, 1,35-54.https://doi.org/10.20958/uis.2015.3 
Tanaka, Y. (2006). Predictability and flexibility in the law of maritime delimiation. Oxford \& Portland: Hart.

Tanko, M., \& Burke, M. (2016). Transport innovations and their effect on cities: the emergence of urban linear ferries worldwide. Presented at the 14th World Conference on Transport Research, Shanghai.

Thompson, R., Burroughs, R., \& Smythe, T. (2006). Exploring the connections between ferries and urban form: some considerations before jumping on board. Journal of Urban Technology, 13(2), 25-52. https://doi.org/10.1080/10630730600872021

Tiry, C. (2003). Hong Kong, an urban future shaped by rail transport. China Perspectives, 49.

Toland, A. (2017). Hong Kong's artificial anti-archipelago and the unnaturing of the natural. In

A. Rademacher \& K. Sivaramakrishnan (Eds.), Places of nature in ecologies of urbanism (pp. 87-107). Hong Kong: Hong Kong University Press.

Transport for London. (2013). River action plan. London: Transport for London. Retrieved from http://content.tfl.gov.uk/river-action-plan.pdf

Tsai, C.-H. (Patrick), Mulley, C., Burke, M., \& Yen, B. (2015). Exploring property value effects of ferry terminals: evidence from Brisbane, Australia. Journal of Transport and Land Use, 10(1), 119-137. https://doi.org/10.5198/jtlu.2015.562

Tsuen Wan District Council. (2013). 9th Meeting of the Traffic and Transport Committee. Retrieved from

http://www.districtcouncils.gov.hk/tw/doc/2012 2015/tc/committee meetings minute s/TTC/T\&TC (9) Minutes.pdf

Ure, G., \& Wong, M. (1991). Transport in Hong Kong: coping with change. Built Environment, 17(2), 92-106.

Vannini, P. (2011). Constellations of (in-)convenience: disentangling the assemblages of Canada's west coast island mobilities. Social \& Cultural Geography, 12(5), 471-492. https://doi.org/10.1080/14649365.2011.588803

Vannini, P., \& Taggart, J. (2013). Doing islandness: a non-representational approach to an island's sense of place. Cultural Geographies, 20(2), 225-242. https://doi.org/10.1177/1474474011428098

Walker, J. (2012). Human transit: how clearer thinking about public transit can enrich our communities and our lives. Washington, DC: Island Press. https://doi.org/10.5822/978-1-61091-174-0

Wan, S. C.-C. (2015). Selling 107 'No Man Islands' [Photography]. Retrieved from http://www.thephotocrafters.org/exhibitions/nomanisland/

Wang, D.Z.W., \& Lo, H.K. (2008). Multi-fleet ferry service network design with passenger preferences for differential services. Transportation Research Part B: Methodological, 42(9), 798-822. https://doi.org/10.1016/j.trb.2008.01.008

Weisbrod, R.E., \& Lawson, C.T. (2003). Ferry systems: planning for the revitalization of U.S. cities. Journal of Urban Technology, 10(2), 47-68. https://doi.org/10.1080/1063073032000139697

Wilbur Smith and Associates. (1976). Hong Kong comprehensive transport study. Hong Kong: Hon Kong Government Printer.

Wong, H. (1998). The future role of ferry services in Hong Kong. Masters Dissertation. Hong Kong: University of Hong Kong.

Yeoman, I., John Lennon, J., Blake, A., Galt, M., Greenwood, C., \& McMahon-Beattie, U. (2007). Oil depletion: what does this mean for Scottish tourism? Tourism Management, 28(5), 1354-1365. https://doi.org/10.1016/j.tourman.2006.09.014 